\title{
Chinese multinationals in Spain: Determinants of establishment mode choice
}

\section{Multinacionales chinas en España: determinantes de la elección del modo de establecimiento}

\author{
Diego Quer Ramón ${ }^{1}$ \\ Enrique Claver Cortés ${ }^{1}$ \\ LAURA RIENDA García ${ }^{1}$ \\ University of Alicante (Spain)
}

Recibido el 1 de junio de 2015, aceptado el 9 de diciembre de 2015

Publicado online el 4 de mayo de 2016

$\mathrm{N}^{\circ}$ de clasificación JEL: F23

DOI: $10.5295 / \mathrm{cdg} .150548 \mathrm{dq}$

\begin{abstract}
:
Since the beginning of the $21^{\text {st }}$ century, Chinese multinational enterprises (MNEs) are emerging as major global players. Some of them have carried out significant foreign direct investments (FDIs) in developed countries. The main objective of these outward FDIs is to access strategic assets like internationally recognised brands or technological and managerial know-how. As a result, Chinese MNEs are receiving increasing attention in the international management literature. The study of these emerging-market MNEs has generated an interesting epistemological debate among researchers on the applicability of traditional theoretical frameworks. The main question is whether conventional arguments originated in MNEs coming from developed-countries are still valid in the case of developing-country MNEs. While some scholars argue that the analysis of emerging-market MNEs requires new theory, others argue that no new theory is required. Drawing on the transaction cost theory, this paper aims to contribute to this debate by analysing the determining factors of establishment mode choice by Chinese MNEs, namely the choice between acquisition and greenfield investment. From a sample of 88 Spanish subsidiaries of Chinese companies, results show that strategic asset-seeking and a lower growth rate of the Spanish economy are associated with a greater preference for acquisitions. However, industry's technological intensity turned out to be not significant.
\end{abstract}

Keywords:

Chinese multinationals, Spain, establishment mode.

\section{Resumen:}

Desde el inicio del siglo XXI, las multinacionales chinas se están erigiendo en actores principales del nuevo escenario global. Algunas de ellas han efectuado inversiones importantes en países desarrollados con la finalidad de conseguir activos estratégicos como marca o know-how. Estas multinacionales chinas están recibiendo una creciente atención en la literatura sobre dirección internacional de la empresa. Como consecuencia, se ha

\footnotetext{
${ }^{1}$ Department of Management. P.O. Box 99, E-03080 Alicante (Spain).diego.quer@ua.es; enrique.claver@ua.es; laura.rienda@ua.es
} 
suscitado un debate académico sobre si los marcos teóricos convencionales resultan aplicables para explicar su comportamiento internacional o si se necesitan nuevos modelos teóricos que se adapten mejor a sus peculiaridades como multinacionales procedentes de una economía emergente. Nuestro trabajo pretende contribuir a este debate analizando, desde la teoría de los costes de transacción, los factores determinantes del modo de establecimiento utilizado por las empresas chinas, es decir, la elección entre adquisiciones o nuevas filiales propias. A partir de una muestra de 88 empresas radicadas en España con participación china, nuestros resultados indican que la búsqueda de activos estratégicos y una menor tasa de crecimiento de la economía española se asocian con una mayor preferencia por las adquisiciones en detrimento de las nuevas filiales propias. Sin embargo, la intensidad tecnológica del sector no resulta significativa en la elección del modo de establecimiento.

\section{Palabras clave:}

Multinacionales chinas, España, modo de establecimiento. 


\section{INTRODUCTION}

Ever since China started to open up in 1978, it became one of the top destinations worldwide for foreign direct investment (FDI), either because this was the best formula to make the most out of the country's production costs, or because of the Chinese market's potential. This process, however, has reverted in the last few years: China is now becoming one of the most important sources of outward FDI, with investments made by Chinese companies abroad growing exponentially. Between 2007 and 2014, in just seven years, China's outward FDI flows increased four-fold, reaching 116,000 million dollars in 2014 and placing mainland China as the third investor in the world, only after the United States and Hong Kong, China (UNCTAD 2015).

Despite the fact that Spain had never been a traditional investment destination for China, the trend started to change in 2010, when some Chinese multinational enterprises (MNEs) engaged into significant investments in this country. Some examples of this new investment wave in Spain for strategic asset-seeking are the arrival of telecommunications company ZTE in the Basque Country (where it has established its Southern-European headquarters) and the increasing participation of Chinese companies in well-known Spanish brands, such as NH Hoteles, Osborne, and Campofrío.

Research on Chinese investments in Spain is, so far, scarce and mostly descriptive (Goy and Navarro 2008; Santacana and Wang 2008; Hernández and Álvarez 2009; Sáez 2010; Carril and Milgram 2014; ESADE 2014; Quer et al. 2015). In these studies, no detailed analyses on some FDI-related decisions made by Chinese companies in Spain have been conducted (such as the entry mode chosen for entering the market).

Entry mode choice is one of the most frequently researched topics in the international business literature. It is important to note the difference between entry modes that do not require an FDI (exports or contractual agreements) and those that do necessarily require one. Among the entry modes that do require an FDI, there is a series of different modalities that can be classified in two different ways. First, the company may retain full ownership of the facilities in the foreign country (wholly-owned subsidiary), or share ownership with a partner (joint venture). This is known as ownership mode (Brouthers and Hennart 2007). Second, the company may create a new subsidiary (greenfield investment) or to acquire a company that was already established in the host country (acquisition). This second decision is known as establishment mode choice (Cho and Padmanabhan 1995; Slangen and Hennart 2007). This study focuses on this last aspect, that is, on how Chinese companies decide which establishment mode to choose to do business in Spain.

The aim of this paper is to analyse the factors that influence Chinese companies' establishment mode choice in Spain, using transaction cost considerations as a basis. More specifically, it is focused on analysing the influence of the following factors: technological intensity within the sector where the company operates (as a key factor influencing the specific advantages that the company seeks to exploit), search for strategic assets (as a key factor influencing the type of assets that the company wants to access), and the growth rate of the host economy (as a way to assess the availability of specific assets or location advantages in the host country).

In order to do so, the paper is structured into several sections. First of all, it offers a literature review and proposes a series of hypotheses on the influence of the above-men- 
tioned factors when it comes to establishment mode choice. Then, the methods used to test the hypotheses are described, the results obtained are presented, and the main conclusions are explained.

\section{LITERATURE REVIEW AND HYPOTHESES DEVELOPMENT}

Transaction Cost Theory (TCT) is the most widely used conceptual framework for explaining entry mode choice (Slangen and Hennart 2007). This theoretical framework was first developed within international business by Buckley and Casson (1976), Rugman (1981) and Hennart (1982) through the so-called internalisation theory, which became one of the most influential conceptual frameworks in the international business literature. TCT analyses entry mode choice from the point of view of cost, profit and alternatives for investment (Larimo 2003). According to TCT, a company will undertake FDI if the cost of engaging into international transactions in a market (exports) is higher than that of conducting business by establishing subsidiaries in other countries (Hennart 1982). Drawing on the TCT, both internalisation theory and Dunning's (1981) eclectic paradigm (one of the most influential models) would support the decision of conducting an FDI whenever a company needs to combine two types of assets: firm-specific advantages that can be transferred to other countries, and location-specific or country-specific advantages.

Thus, FDI allows companies to combine their very own, specific, original advantages with assets available in the host country (Hennart and Park 1993). These local complementary assets (known as "country-specific assets" in the internalisation theory, and as "location advantages" in the eclectic paradigm) are not always available for foreign companies to access directly, and therefore they sometimes have to incur in high transaction costs to access them (Hennart 2009).

Hennart and Park (1993) extend the TCT and state that a company's decision to acquire an already existing company or establish a greenfield subsidiary depends ultimately on the specific advantages that it is seeking to transfer or to access in the host country. More precisely, they believe that if a company's specific advantages are based upon a series of capabilities that can be separated from the organisation itself, then these capabilities can be exploited together with those of an acquired company. However, if a company's specific advantages are tightly bound to the organisation itself (e.g. human resources know-how and abilities), the most efficient way to exploit them is to establish a new subsidiary that has the same characteristics as the parent company.

To sum up, it is the nature of the assets involved in the transaction (both those that the company intends to exploit abroad and those it wants to access), together with the availability of local complementary assets in the host country, that will determine the choice between acquisition and greenfield investment.

The aim of this paper is to analyse the factors that influence Chinese companies' establishment mode choice in Spain, using TCT considerations as a basis and focusing on the influence of three specific factors: industry's technological intensity, strategic assetseeking, and economy's growth rate. 


\subsection{Industry's technological intensity}

The technological intensity of the industry has a direct influence on FDI-related decisions (Kumar 1984; Chen and $\mathrm{Hu}$ 2002). When it comes to choice of establishment mode, a series of TCT-based arguments allow us to associate higher technological intensity with a preference towards creating new subsidiaries instead of acquiring already existing companies. Larimo (2003) claims that a company where R\&D intensity is higher will choose to establish a new subsidiary in order to better preserve and exploit its technological assets, whereas a lower technological intensity company will probably tend to seek the knowledge it needs by acquiring an already existing company that owns it.

Moreover, specific knowledge is easier to transfer to a new subsidiary owned by the company than to an acquired company, since it will be implemented from the very beginning (Slangen and Hennart 2008). Greenfield investments make it possible to avoid undertaking the acquired company's human resources, and so new subsidiaries can be shaped as per the parent company's needs from the very beginning (Hennart and Park 1993).

There is abundant empirical evidence of the negative relationship between technological intensity and a preference for acquisitions (Hennart and Park 1993; Cho and Padmanabhan 1995; Brouthers and Brouthers 2000; Harzing 2002; Larimo 2003; Rienda et al. 2013). Although no previous studies analysed this relation in the case of Chinese MNEs, building on the above-mentioned TCT-based grounds, the first hypothesis is proposed as follows:

Hypothesis 1. A greater industry's technological intensity is negatively related to Chinese companies' preference for acquisitions as the establishment mode in Spain.

\subsection{Strategic asset-seeking}

It has traditionally been established that there are four main reasons why a company would choose FDI as the entry mode (Dunning 1993): resource-seeking (mainly low-cost), market-seeking (in the destination country or its neighbouring countries), efficiency-seeking (by rationalising production or marketing activities), and strategic asset-seeking (in order to improve international competitiveness).

During the last few years, the importance of strategic asset-seeking as a factor influencing Chinese outward FDIs has not ceased to grow (Buckley et al. 2007; Rui and Yip 2008; Huang and Renyong 2014; Yang et al. 2014). Strategic assets are scarce, appropriable, specialised resources that are hard to imitate and transfer, thus awarding companies competitive advantage (Amit and Schoemaker 1993). Instead of exploiting an already existing competitive advantage, some Chinese companies choose to improve their competitiveness by accessing intangible resources (such as technology, know-how, experience and trademarks), usually in developed countries (Mathews 2006; Hennart 2012).

Through this strategic asset search, Chinese companies strive to overcome their competitive disadvantages, using those assets to improve their position in national and international markets and therefore being able to compete with companies from advanced countries (Luo and Tung 2007; Guillén and García-Canal 2009; Yang et al. 2014; Meyer 2015). For defenders of traditional theories (according to which firm-specific advantages are essential 
requirements prior to FDI), these FDIs that are aimed at exploring new opportunities rather than exploiting already-existing advantages are a true challenge (Mathews 2006).

TCT-based studies on establishment mode suggest that the choice between acquisitions and greenfield investments will depend on the company's already available capabilities and those that are sought (Slangen and Hennart 2007). Therefore, MNEs in search for opportunities to exploit their technological capabilities might choose a greenfield investment, since it is a more efficient way to transfer knowledge. In contrast, those in search for specific knowledge about their sector or the destination country are more likely to choose an acquisition as a way to obtain that tacit knowledge in a more efficient way.

Some kinds of knowledge (about technology, international operation success, country-specific knowledge, and so on) are very hard to develop internally. Moreover, due to their tacit nature it is also difficult to access that knowledge from outside the companies that own it. For these reasons, companies seeking knowledge are more likely to try to access it via acquisitions (Hennart and Park 1993; Hennart et al. 1996; Larimo 2003).

Some companies from emerging economies may use acquisitions in developed countries as a strategy to obtain intangible resources and capabilities within the field of technology, marketing and business management (Guillén and García-Canal 2009; Elia and Santangelo 2012; Yang et al. 2014). When it comes to Chinese companies, acquisitions have not only been used by large oil, gas and mining companies to access raw materials and power resources; they have also been used by companies from other sectors as a fast way to access technology, R\&D skills, and internationally renowned trademarks (Child and Rodrigues 2005). All in all, Chinese MNEs arrived at the global scene later than others, and so they need to speed up their internationalisation process in order to be at the same level as their already-established competitors. To that end, they use international growth as a springboard to get strategic assets. More specifically, they use acquisition as a means to access technology and trademarks quickly so that they can overtake their competitors (Luo and Tung 2007).

There is empirical evidence to support the relation between strategic asset-seeking and acquisitions carried out by Chinese companies. Deng (2009) observed how Chinese MNEs are increasingly using acquisitions as a way to obtain strategic assets and overcome the pressure exerted by the China's institutional environment. Rui and Yip (2008) proved that Chinese companies perform acquisitions in order to achieve their strategic goals, seeking capabilities that will allow them to balance off their competitive disadvantages and exploit ownership advantages. Therefore, all these arguments lead to the second hypothesis:

Hypothesis 2. Chinese companies looking for strategic assets in Spain choose acquisition as the establishment mode, instead of greenfield investment.

\subsection{Growth rate of the host economy}

As mentioned above, choice of establishment mode is not only determined by the nature of the assets that the company wishes to exploit or access, but also by country-specific assets, also known as location advantages. In TCT terminology, this is the availability of local complementary assets in the host country (Hennart and Park 1993; Hennart 2009). 
In short, host market attractiveness also has a key influence on establishment mode choice (Demirbag et al. 2008; Morschett et al. 2010), and that is why the destination country's economic growth rate is one of the most thoroughly studied factors in the literature.

There is an argument suggesting that acquisitions are preferred whenever the destination country's economic growth rate is low. Low-growth markets like the European Union provide fewer opportunities to increase production capacity, but more to acquire rival companies when they are going through difficult times (Yip 1982). In such markets, acquisitions are a better establishment mode than greenfield investments, since they do not increase global production capacity within the industry, thus reducing the risk of retaliation from already-established competitors (Brouthers and Brouthers 2000). On the contrary, markets with a high growth rate can bear an increase in production capacity, which means establishing a greenfield subsidiary would be the best option (Larimo 2003). Also, there is abundant empirical evidence of the negative relationship between the host country's economy growth rate and acquisitions being used as the establishment mode (Brouthers and Brouthers 2000; Larimo 2003; Rienda et al. 2013).

Although there is not specific evidence of this fact in Chinese MNEs, given that this paper analyses the investments made in a European-Union member state by companies coming from an emerging economy, following the above-mentioned arguments, the third hypothesis is proposed as follows:

Hypothesis 3. Spain's higher economic growth rate is negatively related to Chinese companies preferring to enter the market by acquiring already-existing companies.

\section{EMPIRICAL RESEARCH METHODS}

\subsection{Sample and data}

The sample was obtained from a series of secondary information sources: first, the registry of Chinese companies operating in Spain that is kept by the ESADE China Europe Club Observatory (ESADE 2014); second, the list of companies established in Spain with shareholders from China and Hong Kong (from SABI -the Iberian Balance sheet Analysis System- database); and third, lists of Chinese companies operating in Spain that are drafted by the Chinese Chamber of Commerce and Investments in Spain, as well as the Office of the Economic and Business Advisor (People's Republic of China's Embassy in Spain).

Other sources were used for data refinement: the China Global Investment Tracker database (provided by The Heritage Foundation, and including large investments made by Chinese companies worldwide), Newsletter Carta de Asia-Economía (by Casa Asia), information published in Chinese media (such as China Daily and Global Times), and data available at the corporate websites of Chinese investing companies. After this information gathering process, a sample of 88 Chinese-participated, Spain-based companies until May 2015 was obtained.

From the geographical point of view, the sample is obviously biased, since $81.8 \%$ of Chinese investments are located in only two Spanish provinces: Madrid (39 companies) and Barcelona (33). According to the data, 1993 was the year when the first of these companies arrived in Spain. However, it is important to highlight that 45 investments have 
been made in the last few years, between 2010 and 2015, which entails a $51.1 \%$ of the whole sample. When it comes to industrial distribution, 73 investments (83\% of the total) are commercial or services-related, while the other 15 investments (17\% of the total) were made in the manufacturing industry. The most widely represented sectors are: solar energy (7 investments), metal, and telecommunications (5 investments each). About the size of Chinese subsidiaries in Spain, small companies prevail: 67 of the companies detected in this study (over $75 \%$ of the total) have less than 50 employees. More specifically, 47 of them have between 1 and 10 employees, while the other 20 have between 11 and 50. With respect to establishment mode, the most popular choice among Chinese companies seems to be greenfield investment (57 companies), followed by establishing a joint venture (12), partial acquisition (12) and a full acquisition (7). Table 1 summarises the main features of Chinese companies included in the sample.

Table 1

Main features of Chinese investments in Spain included in the sample

\begin{tabular}{|c|c|c|}
\hline Variable & Category & Number of observations \\
\hline \multirow{3}{*}{ Location } & Madrid & 39 \\
\hline & Barcelona & 33 \\
\hline & Other provinces & 16 \\
\hline \multirow{2}{*}{ Entry period } & $2010-2015$ & 45 \\
\hline & 1993-2009 & 43 \\
\hline \multirow{2}{*}{ Industry } & Commercial and services & 73 \\
\hline & Manufacturing & 15 \\
\hline \multirow{7}{*}{ Investment sectors } & Solar energy & 7 \\
\hline & Metal & 5 \\
\hline & Telecommunications & 5 \\
\hline & Food & 4 \\
\hline & Chemistry & 4 \\
\hline & Sea freight & 4 \\
\hline & Others & 59 \\
\hline \multirow{2}{*}{ Size of Spanish subsidiary } & Under 50 employees & 67 \\
\hline & 50 or more employees & 21 \\
\hline \multirow{4}{*}{ Entry mode } & Greenfield investment & 57 \\
\hline & Joint venture & 12 \\
\hline & Partial acquisition & 12 \\
\hline & Full acquisition & 7 \\
\hline
\end{tabular}

Source: Drafted by the authors from sample data.

When it comes to Chinese investors, it is important to point out that 57 investments $(64.8 \%)$ were made by privately owned Chinese companies, while the other 31 (35.2\%) were made by state-owned enterprises. With regards to the region in China where they come from, most of the companies in the sample were based in Beijing (28), followed 
by Hong Kong (15), Guangdong (10), Shanghai (9) and Jiangsu (7). Most of them made no more than one investment in Spain, with the sole exceptions of Chint Group (3 investments), Bluestar Group, China Certification \& Inspection Group, China National Fisheries Corporation, Dalian Wanda Group, Sinochem, Suntech Power and ZTE (2 investments each). Table 2 shows the main features of Chinese companies in the sample that have made over one investment in Spain.

Table 2

Main features of Chinese companies in the sample that have made over one investment in Spain

\begin{tabular}{cccccc}
\hline Company & $\begin{array}{c}\text { Type of own- Size (em- } \\
\text { ership } \\
\text { ployees) }\end{array}$ & $\begin{array}{c}\text { Chinese region } \\
\text { where the } \\
\text { company comes } \\
\text { from }\end{array}$ & $\begin{array}{c}\text { Number } \\
\text { of invest- } \\
\text { ments }\end{array}$ & $\begin{array}{c}\text { Industry where } \\
\text { investments are } \\
\text { made in Spain }\end{array}$ \\
\hline Chint Group & Private & 29,000 & Shanghai & 3 & $\begin{array}{c}\text { Electrical equip- } \\
\text { ment (2) } \\
\text { Solar energy (1) }\end{array}$ \\
\hline Bluestar Group & State-owned & 137,000 & Beijing & 2 & $\begin{array}{c}\text { Chemistry } \\
\text { Animal food }\end{array}$ \\
\hline $\begin{array}{c}\text { China Certification } \\
\text { \& Inspection Group }\end{array}$ & State-owned & 16,000 & Beijing & 2 & $\begin{array}{c}\text { Import-export } \\
\text { inspection }\end{array}$ \\
\hline $\begin{array}{c}\text { China National Fish- } \\
\text { eries Corporation }\end{array}$ & State-owned & 20,000 & Beijing & 2 & Fishing \\
\hline $\begin{array}{c}\text { Dalian Wanda Group } \\
\text { Sinochem }\end{array}$ & Private & 80,000 & Beijing & 2 & $\begin{array}{c}\text { Real Estate } \\
\text { Football }\end{array}$ \\
\hline Suntech Power & Private & 10,000 & Jiangsu & 2 & $\begin{array}{c}\text { Colar energy } \\
\text { Consulting (re- } \\
\text { newable energies) }\end{array}$ \\
\hline ZTE & 50,000 & Beijing & 2 & Chemistry \\
\hline & Private & 69,000 & Guangdong & 2 & $\begin{array}{c}\text { Telecommunica- } \\
\text { tions }\end{array}$ \\
\hline
\end{tabular}

Source: Drafted by the authors from sample data.

\subsection{Dependent variable}

Establishment mode. The dependent variable in this study is the establishment mode chosen by Chinese companies to engage in business in Spain. This is a dichotomous variable where (1) stands for Chinese companies who have conducted acquisitions in Spain, and (0) otherwise, i.e., meaning that the company has decided to set up a greenfield subsidiary (Hennart and Park 1993; Brouthers and Brouthers 2000; Harzing 2002; Larimo 2003; Slangen and Hennart 2008; Rienda et al. 2013; Meyer et al. 2014). Using the criteria set forth by Barkema and Vermeulen (1998) and Brouthers and Hennart (2007), joint ventures are classified as greenfield investments. 


\subsection{Independent variables}

Industry's technological intensity. In order to measure technological intensity in industries where Chinese companies have invested, they have been classified into three technological levels (Chen and Hu 2002; Larimo 2003; Pangarkar and Yuan 2009; Rienda et al. 2013), based upon OCDE's (2001) proposal: (1) low-technology manufacturing industries and service industries that are not knowledge-intensive; (2) medium-low and medium-high technology manufacturing industries; (3) high-technology manufacturing industries and knowledge-intensive service industries. Table 3 is a summary of this industrial classification.

Table 3

\section{Industrial classification according to technological intensity}

\begin{tabular}{|c|c|c|c|c|c|}
\hline \multicolumn{2}{|c|}{$\begin{array}{l}\text { Low-technology manufactu- } \\
\text { ring industries and service } \\
\text { industries that are not } \\
\text { knowledge-intensive }\end{array}$} & \multicolumn{2}{|c|}{$\begin{array}{c}\text { Medium-low and } \\
\text { medium-high technology } \\
\text { manufacturing indus- } \\
\text { tries } \\
\end{array}$} & \multicolumn{2}{|c|}{$\begin{array}{l}\text { High-technology manufacturing } \\
\text { industries and knowledge-intensive } \\
\text { service industries }\end{array}$} \\
\hline $\begin{array}{l}\text { - Wood } \\
\text { - Paper } \\
\text { - Food \& } \\
\text { drinks }\end{array}$ & $\begin{array}{l}\text { - Textile indus- } \\
\text { try } \\
\text { - Other manu- } \\
\text { factured } \\
\text { goods } \\
\text { - Other services }\end{array}$ & $\begin{array}{l}\text { - Plastic } \\
\text { - Metal } \\
\text { - Electri- } \\
\text { cal } \\
\text { devices } \\
\text { - Motor } \\
\text { vehicles }\end{array}$ & $\begin{array}{l}\text { - Chemical } \\
\text { products (non- } \\
\text { pharmaceu- } \\
\text { tical) } \\
\text { - Equipment for } \\
\text { transport } \\
\text { - Oil-based } \\
\text { products }\end{array}$ & $\begin{array}{l}\text { - Aeronautics } \\
\text { - Pharmaceutics } \\
\text { - Computer tech- } \\
\text { nology } \\
\text { - Telecommunica- } \\
\text { tions } \\
\text { - Medical equip- } \\
\text { ment } \\
\text { - Financial ser- } \\
\text { vices }\end{array}$ & $\begin{array}{l}\text { - Information } \\
\text { and } \\
\text { communication } \\
\text { services } \\
\text { - Technical, } \\
\text { scientific and } \\
\text { professional } \\
\text { services }\end{array}$ \\
\hline
\end{tabular}

Source: OCDE (2001).

Strategic asset-seeking. This is a dummy variable. Value (1) is assigned whenever the goal of a Chinese company in Spain is to search for strategic assets (brands, technology, know-how, etc.), and value (0) is used when it is not (Yang et al. 2014). Each company's goal has been defined by thoroughly analysing a series of external, secondary information sources, mainly news articles on their investment decisions (published in Chinese and Spanish media), and each company's corporate website. In this research, it was considered that a company's investment was meant to seek strategic assets (category 1) whenever press releases published by its managers and information available on the corporate website stated that the Chinese company was investing in Spain in order to improve its collection of intangible strategic assets, with a special emphasis on technological, commercial or managerial resources. In order to do so, keywords such as "brand", "technology", "knowhow" and "knowledge" were used. Consequently, investments have been given value (0) whenever the information available implied that the company was trying to access the Spanish market by setting up a sales subsidiary, seeking natural resources or looking for access to raw materials. To come to this classification, the keywords used were "sales", "market", "distribution", "commercial", "sourcing" and "supply". 
GDP growth rate in Spain. The aim of this variable is to assess how important growth of Spanish economy is when it comes to choosing an establishment mode. The measure was the Spanish GDP growth rate registered the year before a specific Chinese company entered the market. Data were obtained from the World Bank (Barkema and Vermeulen 1998; Buckley et al. 2007; Duanmu and Guney 2009; Quer et al. 2011).

\subsection{Control variables}

Besides the above-mentioned independent variables related to each hypothesis, other variables have been taken into account in the analyses, with a view to controlling the effect that other factors might have had on the establishment mode chosen by each Chinese company $^{2}$.

Firm size. Some previous papers reported that the investing firm's size had a positive impact on the probability of choosing an acquisition instead of a greenfield subsidiary (Andersson and Svensson 1994; Larimo 2003). Notwithstanding this, empirical evidence is not conclusive, since other studies have observed a U-shaped relationship (Meyer and Estrin 1997), or even found no statistical significance (Forsgren 1989; Cho and Padmanabhan 1995; Hennart et al. 1996; Barkema and Vermeulen 1998; Padmanabhan and Cho 1999). For this reason, Chinese firm's size was included as a control variable, which was measured by applying a logarithmic transformation to the number of employees (Yang et al. 2014).

State-owned enterprise. One of the unique features of Chinese MNEs is that many of them are state-owned. This is why in the last few years there is growing interest in analysing whether the internationalisation process that these state-owned enterprises are undergoing might pose a challenge to the dominant theoretical frameworks, which are mainly built upon privately-owned companies (Deng 2013). Thus, some recent empirical studies on Chinese MNEs have analysed the influence of state ownership on a series of decisive aspects such as internationalisation drivers, location choice and entry mode. In spite of this, empirical evidence on the impact of state ownership on establishment mode choice is still scarce. In this sense, Meyer et al. (2014) found that state-owned Chinese companies have a stronger preference towards acquisitions instead of greenfield investments, although this preference is weaker in countries with higher institutional and technological development levels. Since this study only analyses one destination country, state or private ownership was just considered as a control, dichotomous variable: value (1) is assigned to state-owned Chinese companies; (0) is for private-owned companies (Cui and Jiang 2012; Duanmu 2012; Meyer et al. 2014).

\footnotetext{
2 As mentioned above, over half of Chinese investments included in the sample $(51.1 \%)$ were made in the last six years (between 2010 and 2015), that is, amidst the grimmest times of the Spanish financial crisis. At the time, many Spanish companies were probably willing to be sold at a low price, which might have favoured Chinese acquisitions. This idea led us to consider the possibility of including one more variable to control this factor: dividing the sample between investments made before and after 2010. However, this control variable had a very high correlation with GDP growth rate in Spain, and so it was not used, since the effect to be analysed was already included in the "GDP growth rate in Spain" variable.
} 
Manufacturing industry. Prior research reports that there might be differences between industries when it comes to choosing acquisition as the establishment mode (Caves 1982). A weaker tendency towards acquisitions has been observed in manufacturing industries (Kogut and Singh 1988). Also, Erramilli and Rao (1993) described how the specific features of service industries (such as the impossibility to separate production from consumption) influence entry mode choice and incline companies towards shared ownership. Moreover, Morosini et al. (1998) elaborated on the influence that the type of industry may have on post-acquisition performance. Nevertheless, there is also empirical evidence suggesting that the type of industry does not affect a company's choice between acquisition and greenfield investment (Slangen and Hennart 2008). For this reason, a dummy variable aimed at controlling the potential effect that type of sector might have on Spain-based Chinese companies was included: (1) manufacturing industry; (0) commercial and service industries.

Level of development in the region of origin. The heart of China's economic development has traditionally been located in the eastern seaside regions, which is where most foreign companies are based. This has caused these regions to open more to the rest of the world (as opposed to what happened to inland regions), thus resulting in the Chinese government providing stronger support to Eastern China companies in terms of outward FDIs (Voss et al. 2010). This favourable institutional environment has a positive impact on outward FDI levels for Chinese companies based in these regions (Liu et al. 2014; Sun et al. 2015), which tend to expand into more developed countries (Wu and Chen 2014), as well as undertake outward FDI as a way to obtain strategic assets (Yang et al. 2014). In order to control the potential influence that this reality might have on establishment mode, a new variable was introduced measuring the level of development in the region of China where the headquarters of each investing company are located. The measure used was the GDP per capita in the region of origin (by means of a logarithmic transformation), obtained from the National Bureau of Statistics of China.

\section{RESULTS}

A binomial logistic regression model was applied for testing the hypotheses, using SPSS statistical package. This statistic model will allow us to estimate the effect that an increase in each independent variable may have on the probability that the dependent variable (in this case, establishment mode) takes the value 1 (acquisition) instead of 0 (greenfield investment). Table 4 shows the bivariate correlations between independent and control variables, while Table 5 reports the results obtained when applying the abovementioned regression model. 
Table 4

\section{Correlation matrix}

\begin{tabular}{lcccccc}
\hline & $\mathbf{1}$ & $\mathbf{2}$ & $\mathbf{3}$ & $\mathbf{4}$ & $\mathbf{5}$ & $\mathbf{6}$ \\
\hline $\begin{array}{l}\text { 1. Industry's technological } \\
\text { intensity }\end{array}$ & & & & & & \\
\hline 2. Strategic asset-seeking & 0.11 & & & & & \\
\hline 3. GDP growth rate in Spain & -0.07 & -0.20 & & & & \\
\hline 4. Firm size & -0.14 & 0.13 & -0.02 & & & \\
\hline 5.State-owned enterprise & -0.03 & -0.00 & 0.12 & $0.22^{*}$ & & \\
\hline $\begin{array}{l}\text { 6. Manufacturing industry } \\
\text { 7. Level of development in the } \\
\text { region of origin }\end{array}$ & $0.39 * *$ & 0.12 & -0.02 & $-0.26^{*}$ & -0.08 & \\
\hline
\end{tabular}

$* \mathrm{p}<0.05 ; * * \mathrm{p}<0.01$

Source: Drafted by the authors from sample data.

Table 5

\section{Results of binomial logistic regression}

\begin{tabular}{lc}
\hline & B-coefficient \\
\hline Independent variables & \\
\hline Industry's technological intensity (H1) & -0.07 \\
\hline Strategic asset-seeking (H2) & $3.09^{* *}$ \\
\hline GDP growth rate in Spain (H3) & $-0.27^{*}$ \\
\hline Control variables & -0.41 \\
\hline Firm size & 0.27 \\
\hline State-owned enterprise & 0.08 \\
\hline Manufacturing industry & -0.12 \\
\hline Level of development in the region of origin & \\
\hline $\begin{array}{l}\text { Global Chi-square: 53.66** } \\
\text { Correct global \%: 84.00 } \\
\text { Dependent variable: (1) acquisition; (0) greenfield invest- }\end{array}$ \\
ment
\end{tabular}

$* \mathrm{p}<0.05 ; * * \mathrm{p}<0.01$

Source: Drafted by the authors from sample data.

As shown in Table 5, results do not provide enough empirical evidence to support the first hypothesis. As expected, industry's technological intensity has a negative influence on the probability of a company undertaking an acquisition $(\beta=-0.07)$, although this effect is not statistically significant.

In contrast, the model shows a positive and statistically significant results regarding acquisitions being used as a means to seek strategic assets $(\beta=3.09, p<0.01)$, which sup- 
ports the second hypothesis. Therefore, Chinese companies that come to Spain in order to access strategic resources (such as trademarks or know-how) prefer to do so by acquiring an already existing company, instead of setting up a greenfield subsidiary.

Concerning the third hypothesis, empirical support was also obtained $(\beta=-0.27, p<0.05)$ to state that the relationship between economic growth rate in the destination country and entry by means of acquisitions is negative. This means that, the lower Spain's economic growth is, the stronger the preference of Chinese MNEs for acquisitions becomes.

When it comes to control variables, the results show that size of the investing company, whether it is state-owned or privately owned, whether it belongs to a manufacturing industry or was established in a more developed Chinese region are factors that have no impact on the choice of establishment mode in Spain.

\section{DISCUSSION}

When testing the first hypothesis, the findings suggest that in industries with higher technological intensity, Chinese MNEs do not feel less inclined towards using acquisitions as the establishment mode in Spain. This means that the results do not confirm the findings of empirical studies on companies from other countries where a significant negative link was drawn between technological intensity and acquisitions (Hennart and Park 1993; Cho and Padmanabhan 1995; Brouthers and Brouthers 2000; Harzing 2002; Larimo 2003; Rienda et al. 2013). As for Chinese MNEs, no prior empirical evidence that could be used as a reference was found. It is true that Zhou et al. (2014) did observe that Chinese companies from industries with high technological intensity were prone to conduct international acquisitions; however, these authors did not perform a specific analysis of establishment mode choice, as an alternative to using a greenfield investment.

The results might be backed by the fact that companies from emerging markets that operate in sectors with high technological intensity have a stronger motivation to expand into developed countries, given that they need access to cutting-edge technology and know-how. High R\&D costs in such sectors motivate these companies to look for markets where prospective income will be enough to get back the money invested in technological development. Also, the need to conquer a certain market share might make these companies take higher risks when entering developed countries (Yamakawa et al. 2008). Sometimes, this may lead to acquisition being chosen over greenfield investment, which would contradict the first hypothesis.

Regarding the second hypothesis, results show that Chinese MNEs seeking strategic assets in Spain prefer to use acquisitions as the establishment mode. This result is in line with what was observed in prior empirical studies on Chinese MNEs (Rui and Yip 2008; Deng 2009). As argued in the hypothesis explanation, in this case, companies prefer acquisitions because they are a faster way to obtain strategic assets (since the acquired company already owns them), and can be frequently found in a country like Spain. If companies were to internally create this kind of intangible resources by establishing a greenfield subsidiary, the process would be much slower. Chinese MNEs, newcomers to the new global scene as they are, need to speed up their internationalisation process if they want to overcome the competitive disadvantages in the face of other competitors from developed countries with a longer internationalisation tradition and expertise. 
With regards to the third hypothesis, empirical support was obtained that proves how a higher economic growth rate in Spain is negatively associated with Chinese MNEs' preference towards acquisitions. Despite the fact that there is no prior empirical evidence on Chinese MNEs specifically, this finding is in line with the conclusions of earlier studies where companies from other countries were analysed (Brouthers and Brouthers 2000; Larimo 2003; Rienda et al. 2013).

Given that this study examines FDI behaviour in companies from an emerging economy that are trying to enter a developed country's market, the results support the arguments posed in this third hypothesis. When the destination country's economy grows more slowly, competitive rivalry rises, which ultimately means it is not interesting for companies to increase the global production capacity by setting up a new subsidiary. Generally speaking, acquisitions can be a way to tackle the risk of already established competitors' seeking retaliation. Furthermore, a time when a country's economy is stagnated may well be an opportunity to purchase already existing companies that are in trouble. During the last few years, Spain has undergone a financial crisis, and so it is possible for certain Chinese companies to have taken advantage of the opportunities arising therefrom.

Table 6 shows a comparison between the results obtained in this paper and the results of other empirical studies that used similar variables.

Table 6

Comparison between empirical studies on establishment mode

\begin{tabular}{|c|c|c|c|c|c|c|}
\hline Study & $\begin{array}{c}\text { Country of } \\
\text { origin }\end{array}$ & $\begin{array}{l}\text { Destination } \\
\text { country }\end{array}$ & $\begin{array}{c}\text { Sample } \\
\text { size }\end{array}$ & $\begin{array}{l}\text { Model } \\
\text { used }\end{array}$ & Variable & $\begin{array}{c}\text { Influence } \\
\text { over acqui- } \\
\text { sition }\end{array}$ \\
\hline \multirow[b]{2}{*}{$\begin{array}{l}\text { Brouthers and } \\
\text { Brouthers } \\
(2000)\end{array}$} & \multirow[b]{2}{*}{ Japan } & \multirow[b]{2}{*}{$\begin{array}{l}\text { Six West- } \\
\text { ern-European } \\
\text { countries }\end{array}$} & \multirow[b]{2}{*}{136} & \multirow[b]{2}{*}{$\begin{array}{l}\text { Binomial } \\
\text { logit }\end{array}$} & $\begin{array}{l}\text { Technologi- } \\
\text { cal intensity }\end{array}$ & - \\
\hline & & & & & $\begin{array}{l}\text { Economic } \\
\text { growth in the } \\
\text { destination } \\
\text { country }\end{array}$ & - \\
\hline $\begin{array}{c}\text { Cho and } \\
\text { Padmanabhan } \\
(1995)\end{array}$ & Japan & Miscellaneous & 756 & $\begin{array}{l}\text { Binomial } \\
\text { logit }\end{array}$ & $\begin{array}{l}\text { Technologi- } \\
\text { cal intensity }\end{array}$ & - \\
\hline Deng (2009) & China & Miscellaneous & 3 & $\begin{array}{l}\text { Case } \\
\text { study }\end{array}$ & $\begin{array}{l}\text { Strategic as- } \\
\text { set-seeking }\end{array}$ & + \\
\hline Harzing (2002) & $\begin{array}{c}\text { Miscella- } \\
\text { neous }\end{array}$ & Miscellaneous & 277 & $\begin{array}{c}\text { Binomial } \\
\text { logit }\end{array}$ & $\begin{array}{l}\text { Technologi- } \\
\text { cal intensity }\end{array}$ & - \\
\hline $\begin{array}{l}\text { Hennart and } \\
\text { Park (1993) }\end{array}$ & Japan & United States & 270 & $\begin{array}{c}\text { Binomial } \\
\text { logit }\end{array}$ & $\begin{array}{l}\text { Technologi- } \\
\text { cal intensity }\end{array}$ & - \\
\hline \multirow[b]{2}{*}{ Larimo (2003) } & \multirow{2}{*}{$\begin{array}{l}\text { Denmark, } \\
\text { Finland, } \\
\text { Norway } \\
\text { and Swe- } \\
\text { den }\end{array}$} & \multirow[b]{2}{*}{ Miscellaneous } & \multirow[b]{2}{*}{3,524} & \multirow[b]{2}{*}{$\begin{array}{l}\text { Binomial } \\
\text { logit }\end{array}$} & $\begin{array}{l}\text { Technologi- } \\
\text { cal intensity }\end{array}$ & - \\
\hline & & & & & $\begin{array}{l}\text { Economic } \\
\text { growth in the } \\
\text { destination } \\
\text { country }\end{array}$ & - \\
\hline
\end{tabular}




\begin{tabular}{|c|c|c|c|c|c|c|}
\hline & & & & & $\begin{array}{l}\text { Technologi- } \\
\text { cal intensity }\end{array}$ & - \\
\hline $\begin{array}{l}\text { Rienda et al. } \\
(2013)\end{array}$ & India & Miscellaneous & 117 & $\begin{array}{l}\text { Binomial } \\
\text { logit }\end{array}$ & $\begin{array}{l}\text { Economic } \\
\text { growth in the } \\
\text { destination } \\
\text { country }\end{array}$ & - \\
\hline $\begin{array}{l}\text { Rui and Yip } \\
\text { (2008) }\end{array}$ & China & Miscellaneous & 3 & $\begin{array}{l}\text { Case } \\
\text { study }\end{array}$ & $\begin{array}{l}\text { Strategic as- } \\
\text { set-seeking }\end{array}$ & + \\
\hline \multirow{3}{*}{ This study } & \multirow{3}{*}{ China } & \multirow{3}{*}{ Spain } & \multirow{3}{*}{88} & \multirow{3}{*}{$\begin{array}{c}\text { Binomial } \\
\text { logit }\end{array}$} & $\begin{array}{l}\text { Technologi- } \\
\text { cal intensity }\end{array}$ & $\begin{array}{l}\text { Not signifi- } \\
\text { cant }\end{array}$ \\
\hline & & & & & $\begin{array}{l}\text { Strategic as- } \\
\text { set-seeking }\end{array}$ & + \\
\hline & & & & & $\begin{array}{l}\text { Economic } \\
\text { growth in the } \\
\text { destination } \\
\text { country }\end{array}$ & - \\
\hline
\end{tabular}

Source: Slangen and Hennart (2007) and own elaboration.

As shown in the table above, the results empirically support two of TCT's conventional claims: that companies' preference towards acquisitions increases when they are looking for strategic assets, and also when economic growth in the destination country is low. Notwithstanding this, the results do not allow us to confirm another basic premise: that higher technological intensity leads companies to use greenfield investments as the establishment mode.

In any case, the analysis would need to thoroughly assess two TCT-related issues that were finally impossible to tackle due to the nature of the data: relative efficiency of markets in terms of local resources that Chinese companies seek, and modularity of acquired assets (Hennart 2009, 2012). On the one hand, the choice between acquiring an already-existing company and establishing a greenfield subsidiary ultimately depends on the markets' relative efficiency for local complementary assets, since some of them are not freely available to foreign investors due to the obvious fact that their legitimate owners want to make them profitable. On the other hand, establishment mode choice also depends on the modularity of the assets to be acquired, this is, on whether it is possible to integrate them into the purchasing company's assets without incurring high coordination costs. As stated by Hennart (2009), acquisitions of local firms will be the preferred establishment mode when the market for these firms is efficient, and the assets they hold are modular. 


\section{CONCLUSIONS}

This study has analysed a phenomenon that has become increasingly important from the academic, political and managerial point of view: FDIs made by MNEs from emerging economies. This paper makes several contributions.

From an academic perspective, this study has provided new evidence on a topic about which not enough empirical analyses had been conducted yet: the relation between the reasons leading companies to engage in FDI, and the type of FDI, in particular on the choice between acquisitions and greenfield investments (Gorynia et al. 2005). Also, this paper helped increase evidence on the type of decisions being made by emerging-market MNEs, a subject that is now attracting major interest in international business. Scholars are currently debating whether traditional theories can be applied to explain these companies' behaviour (which is frequently quite far away from conventional approaches) or new theories need to be developed (Mathews 2006; Rugman 2010; Cuervo-Cazurra 2012; Hennart 2012; Narula 2012).

The contribution of this study to this debate is the analysis of the validity of TCT premises in the specific case of Chinese companies. TCT supports two of the most widely used conceptual frameworks in entry mode research: internalisation theory and the eclectic paradigm. According to these two theoretical frameworks, establishment mode choice is determined by the specific assets that a company wishes to exploit or seek in other countries, as well as the host country's specific assets or location advantages.

This research also focuses on establishment mode choice, a specific topic of Chinese MNEs that has received little attention in the literature. Prior research focused on the factors influencing international acquisitions made by Chinese companies, and explored some of the factors that have also been analysed here, namely strategic asset-seeking (Rui and Yip 2008; Deng 2009) and industry's technological intensity (Zhou et al. 2014). However, there are still very few empirical studies focusing specifically on the choice of establishment mode by Chinese MNEs. Meyer et al. (2014) did indeed study establishment mode choice of Chinese MNEs, but only in terms of the influence exerted by the host country's institutional and technological environment when it comes to choosing between acquisitions and greenfield subsidiaries.

Moreover, this research provides empirical, firm-level data about investments made by Chinese companies in Spain, a phenomenon that has been seldom discussed so far and has only been analysed from a descriptive point of view.

Furthermore, this study also has a series of managerial implications. For over thirty years, China's economic development was based upon exports, which provided considerable financial resources to the country. Nowadays, Chinese companies are using these resources to invest in other countries, hence the growing interest of Spanish companies and institutions in attracting Chinese investors. With regard to direct impact of these investments on the Spanish economy, a two-fold effect is observed: job and wealth creation (direct effect) on the one hand, and the possibility to cooperate more closely with China in the future in order to develop joint business in China or in other countries (indirect effect) on the other hand. This is why it is important to get to know Chinese companies' decision-making processes better, and to observe whether their behaviour is the same or different from that of companies from other countries. In this sense, the contribution lies in the analysis of factors determining one of the most relevant decisions: establishment mode. 
Of course, this study does have limitations. First, only one destination country (Spain) is analysed, which makes it difficult to extrapolate these results to other countries where China undertakes outward FDIs. Second, some of the results might be influenced by the specific features of the sample and the nature of the variables used. Since this study is based on secondary information, some factors (for instance, managers' perceptions on competitive rivalry) that may also have an influence on establishment mode have not been analysed.

Thus, future research based on primary data should consider institutional variables to analyse how these companies (coming from a country with difficult institutional conditions) managed to enter a highly uncertain environment such as the Spanish market during the financial crisis.

Anyway, it becomes necessary to conduct even more thorough analyses on how Chinese MNEs make decisions in Spain and their consequences. Several questions remain unanswered, opening avenues for future research: which competitive strategies do these companies apply in order to compete with local companies and win? Which are the key factors leading them to hire locals or expatriates in their Spanish subsidiaries? How do they adapt their human resources policies to face cultural differences, and how do Spanish employees react to these policies? How do they integrate the acquired companies? What are the consequences of Chinese capital entering Spanish companies, in terms of profitability and job creation?

\section{REFERENCES}

Amit, R. and Schoemaker, P.J.H., 1993. Strategic assets and organizational rent. Strategic Management Journal, 14 (1), 33-46.

Andersson, T. and Svensson, R., 1994. Entry modes for direct investment determined by the composition of firm-specific skills. The Scandinavian Journal of Economics, 96 (4), 551-560.

Barkema, H.G. and Vermeulen, F., 1998. International expansion through start-up or acquisition: a learning perspective. Academy of Management Journal, 41 (1), 7-26.

Brouthers, K.D. and Brouthers, L.E., 2000. Acquisition or greenfield start-up? Institutional, cultural and transaction cost influences. Strategic Management Journal, 21 (1), 89-97.

Brouthers, K.D. and Hennart, J.F., 2007. Boundaries of the firm: Insights from international entry mode research. Journal of Management, 33 (3), 395-425.

Buckley, P.J. and Casson, M.C., 1976. The future of the multinational enterprise. New York: Holmes \& Meier Publishers.

Buckley, P.J., Clegg, L.J., Cross, A.R., Liu, X., Voss, H. and Zheng, P., 2007. The determinants of Chinese outward foreign direct investment. Journal of International Business Studies, 38 (4), 499-518.

Carril, F. and Milgram, J., 2014. Chinese outward FDI in Spain: An analysis of the determinants at the firm level. XI INTECO Workshop on Economic Integration. Valencia, Noviembre.

Caves, R.E., 1982. Multinational enterprise and economic analysis. Cambridge, UK: Cambridge University Press. 
Chen, H. and Hu, M.Y., 2002. An analysis of entry mode and its impact on performance. International Business Review, 11 (2), 193-210.

Child, J. and Rodrigues, S.B., 2005. The internationalization of Chinese firms: A case for theoretical extension? Management and Organization Review, 1 (3), 381-410.

Cho, K.R. and Padmanabhan, P., 1995. Acquisition versus new venture: the choice of foreign establishment mode by Japanese firms. Journal of International Management, 1 (3), 255-285.

Cuervo-Cazurra, A., 2012. Extending theory by analyzing developing country multinational companies: Solving the Goldilocks debate. Global Strategy Journal, 2 (3), 153-167.

Cui, L., and Jiang, F., 2012. State ownership effect on firms' FDI ownership decisions under institutional pressure: A study of Chinese outward-investing firms. Journal of International Business Studies, 43 (3), 264-284.

Demirbag, M., Tatoglu, E. and Glaister, K.W., 2008. Factors affecting perceptions of the choice between acquisition and greenfield entry: The case of Western FDI in an emerging market. Management International Review, 48 (1), 5-38.

Deng, P., 2009. Why do Chinese firms tend to acquire strategic assets in international expansion? Journal of World Business, 44 (1), 74-84.

Deng, P., 2013. Chinese outward direct investment research: Theoretical integration and recommendations. Management Organization Review, 9 (3), 513-539.

Duanmu, J.L. and Guney, Y., 2009. A panel data analysis of locational determinants of Chinese and Indian outward foreign direct investment. Journal of Asia Business Studies, 3 (2), 1-15.

Duanmu, J.L., 2012. Firm heterogeneity and location choice of Chinese Multinational Enterprises (MNEs). Journal of World Business, 47 (1), 64-72.

Dunning, J., 1981. International production and the multinational enterprise. London, UK: George Allen \& Unwin.

Dunning, J.H., 1993. Multinational enterprises and the global economy. Wokingham, UK: Addison-Wesley.

Elia, S. and Santangelo, G.D., 2012. Strategic asset-seeking acquisitions by emerging market multinationals: The role of the industry context. Third Copenhagen Conference on Emerging Multinationals: Outward Investment from Emerging Economies. Copenhagen, Denmark, Octubre.

Erramilli, M.K. and Rao, C.P., 1993. Service firms' international entry-mode choice: A modified transaction-cost analysis approach. Journal of Marketing, 57 (3), 19-38.

ESADE, 2014. Inversión china en Europa 2014. Barcelona: ESADE China Europe Club.

Forsgren, M., 1989. Foreign acquisitions: internalization or network interdependency? En: Cavusgil, S.T., ed. Advances in international marketing 3. Greenwich, CT: JAI Press, 141-159.

Gorynia, M., Nowak, J. and Wolniak, R., 2005. Motives and modes of FDI, firm characteristics and performance: Case studies of foreign subsidiaries in Poland. Journal of Transnational Management, 10 (3), 55-87.

Goy, A.M. and Navarro, A., 2008. ¿Cómo fomentar la inversión asiática en España? Madrid: Observatorio de Política Exterior Española. Fundación Alternativas. Documento de Trabajo 18/2008. 
Guillén, M.F. and García-Canal, E., 2009. The American model of the multinational firm and the "new" multinationals from emerging economies. Academy of Management Perspectives, 23 (2), 23-25.

Harzing, A.W., 2002. Acquisitions versus greenfield investments: International strategy and management of entry modes. Strategic Management Journal, 23 (3), 211-227.

Hennart, J.F. and Park, Y.R., 1993. Greenfield vs. acquisition: The strategy of Japanese investors in the United States. Management Science, 39 (9), 1054-1070.

Hennart, J.F., 1982. A theory of multinational enterprise. Ann Arbor, MI: University of Michigan Press.

Hennart, J.F., 2009. Down with MNE-centric theories! Market entry and expansion as the bundling of MNE and local assets. Journal of International Business Studies, 40 (9), 1432-1454.

Hennart, J.F., 2012. Emerging market multinationals and the theory of the multinational enterprise. Global Strategy Journal, 2 (3), 168-187.

Hennart, J.F., Larimo, J. and Chen, S.F., 1996. Does national origin affect the propensity of foreign investors to enter the United States through acquisitions? Vaasa, Finland: Proceedings of the University of Vaasa. Discussion paper no. 189.

Hernández, A. and Álvarez, O., 2009. China, nuevo actor de la inversión extranjera global. Boletín Económico de ICE, № 2972, 165-175.

Huang, X. and Renyong, C., 2014. Chinese private firms' outward foreign direct investment: Does firm ownership and size matter? Thunderbird International Business Review, 56 (5), 393-406.

Kogut, B. and Singh, H., 1988. The effect of national culture on the choice of entry mode. Journal of International Business Studies, 19 (3), 411-432.

Kumar, N., 1984. Growth, acquisition and investment: An analysis of the growth of industrial firms and their overseas activities. Cambridge, UK: Cambridge University Press.

Larimo, J., 2003. Form of investment by Nordic firms in world markets. Journal of Business Research, 56 (10), 791-803.

Liu, X., Lu, J. and Chizema, A., 2014. Top executive compensation, regional institutions and Chinese OFDI. Journal of World Business, 49 (1), 143-155.

Luo, Y. and Tung, R.L., 2007. International expansion of emerging-market enterprises: A springboard perspective. Journal of International Business Studies, 38 (4), 481-498.

Mathews, J.A. (2006): Dragon multinationals: New players in 21st century globalization. Asia Pacific Journal of Management, 23 (1), 5-27.

Meyer, K.E. and Estrin, S., 1997. Privatisation acquisition and direct foreign investment: who buys state-owned enterprises? MOST: Economic Policy in Transitional Economies, 7 (1), 159-172.

Meyer, K.E., 2015. What is "strategic asset seeking FDI"? Multinational Business Review, 23 (1), 57-66.

Meyer, K.E., Ding, Y., Li, J. and Zhang, H., 2014. Overcoming distrust: How state-owned enterprises adapt their foreign entries to institutional pressures abroad. Journal of International Business Studies, 45 (8), 1005-1028.

Morosini, P., Shane, S. and Singh, H., 1998. National cultural distance and cross-border acquisition performance. Journal of International Business Studies, 29 (1), 137-158. 
Morschett, D., Schramm-Klein, H. and Swoboda, B., 2010. Decades of research on market entry modes: What do we really know about external antecedents of entry mode choice? Journal of International Management, 16 (1), 60-77.

Narula, R., 2012. Do we need different frameworks to explain infant MNEs from developing countries? Global Strategy Journal, 2 (3), 188-204.

OCDE, 2001. OECD Science, technology and industry scoreboard 2001. Paris: OECD Publications Service.

Padmanabhan, P. and Cho, K.R., 1999. Decision-specific experience in foreign ownership and establishment strategies: evidence from Japanese firms. Journal of International Business Studies, 30 (1), 25-44.

Pangarkar, N. and Yuan, L., 2009. Location in internationalization strategy: Determinants and consequences. Multinational Business Review, 17 (2), 37-68.

Quer, D., Claver, E. and Rienda, L., 2011. Multinacionales chinas: ¿cómo influyen los factores institucionales en sus patrones de localización? Cuadernos de Gestión, 11 (2), 77-88.

Quer, D., Claver, E. and Rienda, L., 2015. Las multinacionales chinas en España: situación actual y retos de futuro. Boletín Económico de ICE, $\mathrm{N}^{\circ}$ 3064, 35-44.

Rienda, L., Claver, E. and Quer, D., 2013. The internationalisation of Indian multinationals: determinants of expansion through acquisitions. Journal of the Asia Pacific Economy, 18 (1), 115-132.

Rugman, A.M., 1981. Inside the multinationals: The economics of internal markets. London: Croom Helm.

Rugman, A.M., 2010. Book review: Globalization of Chinese enterprises. The International Trade Journal, 24 (3), 352-354.

Rui, H. and Yip, G.S., 2008. Foreign acquisitions by Chinese firms: A strategic intent perspective. Journal of World Business, 43 (2), 213-226.

Sáez, L., 2010. Chinese outward direct investments in Spain. London, UK: Chatam House. International Economics Programme Paper 2010/06.

Santacana, R. and Wang, Y.J., 2008. Privatización e internacionalización: Las empresas chinas en España. IX Congreso Internacional de la Asociación Española de Historia Económica. Murcia, Septiembre.

Slangen, A. and Hennart, J.F., 2007. Greenfield or acquisition entry: A review of the empirical foreign establishment mode literature. Journal of International Management, 13 (4), 403-429.

Slangen, A. and Hennart, J.F., 2008. Do multinationals really prefer to enter culturally distant countries through greenfields rather than through acquisitions? The role of parent experience and subsidiary autonomy. Journal of International Business Studies, 39 (3), 472-490.

Sun, S.L., Peng, M.W., Lee, R.P. and Tan, W., 2015. Institutional open access at home and outward internationalization. Journal of World Business, 50 (1), 234-246.

UNCTAD, 2015. World Investment Report 2015: Reforming international investment governance. New York and Geneva: United Nations Conference on Trade and Development. 
Voss, H., Buckley, P.J. and Cross, A.R., 2010. The impact of home country institutional effects on the internationalization strategy of Chinese firms. Multinational Business Review, 18 (3), 25-48.

$\mathrm{Wu}, \mathrm{J}$. and Chen, X., 2014. Home country institutional environments and foreign expansion of emerging market firms. International Business Review, 23 (5), 862-872.

Yamakawa, Y., Peng, M.W. and Deeds, D.L., 2008. What drives new ventures to internationalize from emerging to developed economies? Entrepreneurship Theory and Practice, 32 (1), 59-82.

Yang, Y., Yang, X., Chen, R. and Allen, J.P., 2014. What drives emerging-economy outbound FDI decisions to obtain strategic assets? Asian Business \& Management, 13 (5), 379-410.

Yip, G.S., 1982. Diversification entry: Internal development versus acquisition. Strategic Management Journal, 3 (4), 331-345.

Zhou, C., van Witteloostuijn, A. and Zhang, J., 2014. The internationalization of Chinese industries: Overseas acquisition activity in Chinese mining and manufacturing industries. Asian Business \& Management, 13 (2), 89-116. 